Article

\title{
A Review of the Role of Social Media for the Cultural Heritage Sustainability
}

\author{
Xiaoxu Liang ${ }^{1}{ }^{(\mathbb{C}}$, Yanjun $\mathrm{Lu}^{2}$ and John Martin ${ }^{3, *(\mathbb{D}}$ \\ 1 Department of Architecture and Design, Politecnico di Torino, 10125 Turin, Italy; xiaoxu.liang@polito.it \\ 2 School of Architecture \& Urban Planning, Chongqing University, Chongqing 400030, China; \\ yanjun.luuu@gmail.com \\ 3 Sustainable Earth Institute, University of Plymouth, Plymouth PL4 8AA, UK \\ * Correspondence: J.Martin-2@plymouth.ac.uk
}

check for

updates

Citation: Liang, X.; Lu, Y.; Martin, J. A Review of the Role of Social Media for the Cultural Heritage Sustainability. Sustainability 2021, 13, 1055. https://doi.org/10.3390/ su13031055

Academic Editor: Pier Luigi Sacco

Received: 23 December 2020

Accepted: 12 January 2021

Published: 20 January 2021

Publisher's Note: MDPI stays neutral with regard to jurisdictional claims in published maps and institutional affiliations.

Copyright: (c) 2021 by the authors. Licensee MDPI, Basel, Switzerland. This article is an open access article distributed under the terms and conditions of the Creative Commons Attribution (CC BY) license (https:// creativecommons.org/licenses/by/ $4.0 /)$.

\begin{abstract}
During the last 20 years, with the development of Information and Communication Technologies (ICTs), an emerging interest has appeared in Digital Community Engagement (DCE) in the process of cultural heritage management. Due to a growing need to involve a broader community in the Historic Urban Landscape approach, social media are considered one of the most important platforms to promote the public participation process of urban heritage conservation in the context of rapid urbanization. Despite the growing literature on DCE, which has delivered a general overview of different digital technologies and platforms to enhance heritage conservation, little research has been done on taking stock of the utilization of social media in this process. This study aims to fill the research gap by providing a more comprehensive picture of the functionalities of social media platforms and their impacts on sustainable urban development through a systematic literature review. As a result, 19 out of 248 DCE relevant articles are selected as objects to illustrate the contribution of social media. The study identified the characteristics of these applied social media tools, explores their roles and influences in cases. The article concludes that social media offers a platform for a wider range of stakeholders to have a voice in the decision process of cultural heritage management, and it should be widely applied to encourage citizens from all over the world.
\end{abstract}

Keywords: digital community engagement; social media; cultural heritage management; sustainable urban development

\section{Introduction}

The necessity and importance of paying attention to the participatory method in cultural heritage management are enhanced in the last decades [1]. The 1994 Nara Document on Authenticity cautiously opened the way to a culture-based appreciation of conservation values [2], in 1998, the Stockholm Intergovernmental Conference on Cultural Policies for Development clearly expressed the development dimension of culture [3]. Since then, international practitioners have paid more attention to the diversity of cultural expressions and recognized that an understanding of the diversity of cultures is the solution to ensure an effective and sustainable link between a society and its heritage [3]. People-centered approaches are clearly challenging the established principles defined by both materialbased approaches and values-based approaches [4,5]. In line with it, the Historic Urban Landscape approach is recommended by UNESCO as a "bottom-up" expression of social values and social choice which can better recognize cultural diversity and the dynamic nature of urban heritage in the context of rapid globalization [6,7].

The role of community in sustainable cultural heritage management has been highlighted at UNESCO conferences since 1994 (the publication of the Nara Document on Authenticity) and echoed in the global dimension [8-10]. The "community engagement tools" are listed as one of the expanded conservational instruments by the Historic Urban Landscape approach among "regulatory systems", "technical tools (knowledge and 
planning tools)", and "financial tools" of the Historic Urban Landscape approach, which contributes to long-term sustainable and inclusive urban development [11,12]. In which, the identification of the core and the broader community is the priority to involve stakeholders $[4,10]$. The core community refers to the residents who are living in or nearby the heritage site, while other facilitators such as authorities, experts, and economic actors are recognized as the broader community $[13,14]$. Local communities can share responsibilities of integrating heritage conservation in sustainable urban development through community collaboration and empowerment [6,15-17].

\section{Current Approaches to Engagement and Management}

\subsection{The New Form of Community: Online Community}

The internet, as a kind of social media, could offer a crucial platform that is communitybased for sustainable and holistic heritage conservation [18]. It fosters an open atmosphere such that all the motivated participants can become involved in the cultural heritage protection easily with access to the internet $[19,20]$. Furthermore, ICTs offer an openparticipatory platform, in which citizens can play an active role, to a broader range of stakeholders across scales, classes, races, genders, ages, which is crucial for collaborative planning and conservation [21,22].

Online communities, which are formed with specific cultural practices or gathered by a common topic based on heritage sites or other forms of cultural heritage, have emerged recently accompanied by the arrival of the Web 2.0 era $[18,23,24]$. Compared with offline community engagement, online community communication is totally geo-free, thus, it can promote mutual understandings between people with different cultural backgrounds [25]. People can share their memories or feelings which could be part of the "sense of place" with geographically close people or with a crowd on the other side of the earth [26]. Moreover, it creates more opportunities and breaks the occupational boundary for collaboration between local communities and professionals [27-29]. Taking part in this kind of online community, people can share their knowledge of any aspects of cultural heritage with specialists in the field [30,31], but also gain more opportunities for education outreach [32]. In addition, communications among online communities showcase a far efficient way by being informed and getting feedback easier and faster [33]. They could also leave a comment or chat in real-time with journalists or concerned authorities who are involved in this collaboration [34]

\subsection{Digital Tools to Promote Community Collaboration}

Over time, frontier scholars have shown their interest in studying various ways (co-production, E-education, digital archive, location-based games) that ICTs (e.g., AR, 3D modeling, VR, GIS) including social media have fostered community engagement and collaboration in urban planning and heritage conservation $[35,36]$. Digital interactive applications have been widely used in cultural heritage sites and have hitherto concentrated on community engagement, the equity of multi voices, community empowerment.

Following with technological progress, the integration of digitized presentation and crowdsourcing technology in terms of communication and collaboration for cultural heritage has become a necessary trend [37]. Co-production (also known as co-design, co-creation) as a way of collaborative participation has become increasingly popular in multiple activities, including product design for museums, libraries, and heritage planning [30,31]. Aligned with it, open collections can be used in both formal and informal educational contexts (known as E-education) to share findings and exchange perceptions with stakeholders [38,39]. Furthermore, citizens that gathered as an online community are empowered to create their own digital heritage landscapes, museums, and archives by photo sharing, video-audio records, and narratives [40-42]. In addition, location-based mobile games are utilized to foster in young visitors a larger extent of motivation to explore museums and facilitate their meaning-making process [43-45]. 
Immersive technologies, especially Augmented Reality (AR) based applications can promote the value of industrial heritage and museums across educational, collaborative, and digital technology sectors [46,47]. In the historical industrial site of Carpano (Italy), an AR game was designed to improve visitors' visiting experience by offering industrial, artistic, and historical knowledge [47]. While in a museum of children's literature (UK), AR plays a role as a mediator between targeted audiences (7-11-year-old children) and specialists for collaborative practice [46].

3D modeling and printing technologies are becoming more prevalent in the cultural heritage conservation field without space and time constraints [32,48,49]. Jefferey argues that a site's physical structure can be recorded and deployed by 3D visualizations not only by heritage professionals but also by broader local community groups $[48,49]$. Instead, Champion highlighted the application of 3D models in the preservation of intangible heritage [32].

It is said that the concept of virtual heritage refers to applying Virtual Reality (VR) technology to cultural heritage assets for heritage communication purposes [50,51]. 3D modeling and animations in a video sequence are also involved to represent a better legible solution [50]. However, Hurley shows concern that the current VR applications in the heritage site of Old North St. Louis largely contribute museum displays rather than real participatory planning [51].

Various cultural heritage sites benefit from the concept of crowdsourcing, especially by web-mapping and the analysis from a Geographic Information System (GIS) in mobile $[26,52,53]$. Volunteered Geographic Information (VGI) Data is collected, computed, and visualized based on the Share Our Cultural Heritage (SOCH) web, aiming to document and share cultural heritage worldwide [26]. Meanwhile, the online geospatial heritage database can overcome many of the limitations associated with traditional heritage catalogs [52], both tangible cultural heritage and intangible ones [53].

\subsection{The Role of Social Media in Sustainable Cultural Heritage Management}

Social media apps contribute significantly to collective community memory by storytelling practices and cultural expression by mapping $[25,54,55]$. It is worth mentioning that the definition of social media in this work refers to any digital tool that allows users to quickly create and share content with the public, encompassing a wide range of websites and apps such as the following: (1) photo-sharing apps like Instagram, Flickr; (2) video and audio sharing apps like YouTube; (3) short written message sharing apps like Facebook, Twitter; (4) and other apps designed for geo-location sharing with social interaction functions.

The eagerness of people to obtain relevant real-time information and take part in the planning inspires a lot of potential for involvement both in the use of social media and in addressing them to cultural heritage $[33,56]$. Besides, social media emphasize the equity of discourses by being accessed easily to all Internet users to publish, communicate, read, or broadcast information inexpensively [57]. In terms of time, social media products allow users to publish information and get feedback in near-real-time [58]. Svensson offers a great answer that social media can enable and strengthen people's effective engagement with heritage [59].

Approaches to involving social media in the museums, monuments, and urban heritage sites are on-going and rapidly growing in interest. Some agencies and authorities made an effort in programming and extracting data, such as information on QR codes, to enhance the communication among participants $[21,39,58]$. Another main approach is storytelling by collecting and analyzing narratives, including both short-term comments and blogs, through popular social media apps, such as Facebook, Twitter, and collective memory websites [25,34,54-56]. In parallel, mapping is one of the crucial tools to get an insight into the community mechanism and user's expectations $[25,26,54,59,60]$. Moreover, in some cases, online surveys based on selected platforms are spread to strengthen the right and ability of multi voices $[19,28,33,36,55]$ It should be noted that the methods mentioned 
above are not exclusive of each other. Instead, they are utilized as an integrated toolkit a number of times.

\section{Methodology}

\subsection{Publication Collection}

To identify relevant publications, a stepwise review approach was employed. The review was based on the database of Web of Science (WoS) and included all articles that discussed and presented social media for cultural and urban heritage conservation. A PIST tool was designed by drawing lessons from the PICOS method in the medical field of research to define the keywords of the search preparation [61,62]. The PICOS search tool contains five criteria initially: (1) Population: communities engaged in the cultural heritage management process; (2) Interventions: social media; (3) Comparison: offline community engagement; (4) Outcomes: outcomes of participatory governance; (5) Study design: Statistical analysis of participatory methods in case studies. However, as the PICOS tool does not accommodate terms relating to cultural heritage studies, it has been modified into a "PIST" (population, interventions, settings, timing), a new tool where the Comparison (C), Outcomes (O), Study design (S) were excluded to meet our needs better. Following that, we further supplemented two criteria to limit the objects to the cultural heritage generally: Setting (S): cultural heritage, and Timing (T): duration or date of publication, which intends to further increase the identification of qualitative articles.

A series of keywords and their synonyms is involved, namely public participation, community engagement, civic collaboration/participation, audience collaboration; cultural heritage, urban heritage, historic city, historic district, historic settlement, historic area, historic plan; social media, social network, digital, online. The key features and criteria which lead to corresponding keywords and synonyms are shown in Table 1. In line with it, the search string is defined as "Ts $=((($ Public or communit* or civic or audience $)$ Near $/ 3$ (participat* or engage* or collaborat*))and(((cultur* or urban*) Near $/ 3$ (historic ${ }^{*}$ Near $/ 2$ (Cit* or district* $^{*}$ or settlement ${ }^{*}$ or area* or plan*)) or heritage))and((social Near/3 (media or network*) or digital or online)))". The defined search string was further refined by adding a date range limit (1985-now) and a language setting (English only). In this phase, 248 document results returned by 26 July 2020 .

Table 1. PIST tool and its progress.

\begin{tabular}{|c|c|c|c|c|}
\hline & & Concepts & Content & Keywords/Synonyms \\
\hline \multirow{5}{*}{$\begin{array}{l}\text { Original criteria } \\
\text { setting }\end{array}$} & $\mathrm{P}$ & Population & $\begin{array}{l}\text { Communities engaged in the } \\
\text { cultural heritage } \\
\text { management process }\end{array}$ & $\begin{array}{l}\text { (Public or communit* or civic or } \\
\text { audience }{ }^{*} \text { Near } / 3 \text { (participat* or engage } \\
\text { or collaborat }^{*} \text { ) }\end{array}$ \\
\hline & $\mathrm{I}$ & Intervention & Social media & $\begin{array}{l}\left(\left(\text { social Near } / 3 \text { (media or network }{ }^{*}\right) \text { or }\right. \\
\text { digital or online }))\end{array}$ \\
\hline & $\mathrm{C}$ & Comparison & $\begin{array}{l}\text { Offline community } \\
\text { engagement }\end{array}$ & $\begin{array}{l}\text { We excluded this part because this did not } \\
\text { add value to the search }\end{array}$ \\
\hline & $\mathrm{O}$ & Outcomes & $\begin{array}{l}\text { Outcomes of participatory } \\
\text { governance }\end{array}$ & $\begin{array}{l}\text { We excluded this part because this did not } \\
\text { add value to the search }\end{array}$ \\
\hline & $\mathrm{S}$ & Study design & $\begin{array}{l}\text { Statistical analysis of } \\
\text { participatory methods in } \\
\text { case studies }\end{array}$ & $\begin{array}{l}\text { We excluded this part because this did not } \\
\text { add value to the search }\end{array}$ \\
\hline \multirow{2}{*}{$\begin{array}{l}\text { Additional } \\
\text { criteria setting }\end{array}$} & $\mathrm{S}$ & Setting & Urban cultural heritage & $\begin{array}{l}\text { (culture* or urban*) Near } / 3 \text { (historic }^{*} \\
\text { Near } / 2\left(\text { Cit }^{*} \text { or district }\right. \\
\left.\left.\text { area }^{*} \text { or } \text { plan }^{*}\right)\right)\end{array}$ \\
\hline & $\mathrm{T}$ & Timing & $\begin{array}{l}\text { Duration or date of } \\
\text { publication }\end{array}$ & 1985-present \\
\hline
\end{tabular}




\subsection{Publication Selection}

In order to select accurate relevant-topic cases for analysis, a semi-quantitative methodology was designed and used to draw up low-relevance publications and refine the gained documents. The selection process is detailed into seven steps and two phases related to the accessibility of full paper, language, and content relevance.

The first phase aims to narrow the gained retrieval database by examining the written language and the ability to access it. Firstly, the duplicated articles and chapters by the same author, and with the same abstract and keywords published by different publishers were excluded automatically by the reference management software. Following that, publications produced by the same author on the same case study were excluded after a cautious cross-comparison. Then, four non-English publications were removed. Although restricting the retrieval language as English, there are still some non-English articles involved in the retrieval result with only an English title and abstract, in which one publication was written in Italian and three publications in Korean. The publications with inaccessible full text were excluded due to the lack of detailed case study descriptions. Following this step, the retrieval returned 195 documents.

Aiming to further refine the targeted articles, the irrelevant-content publications were eliminated manually. Studies were first judged as available resources from the title as well as the abstract. Then, the full texts were downloaded and filtered further by skimming. Lastly, some complementary publications were added by manual screening, for which one of the four criteria in PIST is not explicitly mentioned but alternated with metaphors. To be more specific, the "I" of PIST was omitted to retrieving those in which the keyword Social Media was replaced by other phrases such as Digital Storytelling, New Media, etc. The retrieved publications were ordered by relevance and selected manually according to research topics. Studies where the title referred to but did not include specifically two of the subjects (social media, cultural heritage, community engagement) are anyway listed in our extended references, such as those using Digital Storytelling, and New Media to indicate the keyword Social Media. By now, 19 items were finally retained. The result of each selection process is shown in Table 2.

Table 2. The result of each selection progress.

\begin{tabular}{ccl}
\hline Step & $\begin{array}{c}\text { Number of Publications } \\
\text { Retrained }\end{array}$ & \multicolumn{1}{c}{ Selection Progress } \\
\hline 1 & 248 & Publications that were retrieved from Wos \\
\hline 2 & 240 & $\begin{array}{l}\text { Publications retained after } 8 \text { duplicate publications } \\
\text { were excluded }\end{array}$ \\
\hline 3 & 238 & $\begin{array}{l}\text { Publications retained after 2 publication that has the } \\
\text { same case as another publication was excluded }\end{array}$ \\
\hline 4 & 195 & $\begin{array}{l}\text { Publications retained after 4 non-English } \\
\text { publications were excluded }\end{array}$ \\
\hline 5 & 14 & $\begin{array}{l}\text { Publications retained after 39 inaccessible } \\
\text { publications were excluded }\end{array}$ \\
\hline 6 & 19 & $\begin{array}{l}\text { Publications retained after 181 irrelevant-topic } \\
\text { publications were excluded }\end{array}$ \\
\hline
\end{tabular}

\subsection{Quantitative Analyzing Method}

The following criteria were applied to every case study; publication time, case location, the name of cultural heritage object, applied social media, interactive method, direct object, and impact on sustainable cultural heritage management. However, for most publications, there is only one case involved and one cultural heritage object studied so that it is easy to 
manage the information. However, there are still some works containing multi-practical cases. To follow the same set of data collection and analysis logic, we compress multiple cultural heritage objects into one item (e.g., 19 museums in the Netherlands from the same article) but later on, those cases are listed individually for further study.

All the social media tools involved in the practice are listed for further quantitative statistics of the usage frequency of each digital way. Main interactive methods are summarized and classified by interactive forms of expression into seven ways: Official announcement; Exhibition; Communication; Photosharing; Mapping; Storytelling; Crowdsourcing. By listing interactive methods of every case, we can obtain the applying frequency and identify the characteristics of each interactive method. We marked all the social media that were mentioned in the selected articles and summed the amount (weight $=1$ ). Even if there are several different kinds of apps mentioned in the same article, we just consider it as 1 point. For example, in the case of Thessaloniki, a series of apps, such as Collective City Memory App, i-Guide App, and the website http:/ / thesswiki.com/ are used to equip Thessaloniki as a Digital City. Therefore, App and Web would be marked as 1 point respectively. In addition, we evaluated the function of social media on sustainable cultural heritage management both from direct and indirect perspectives, in that way we can explore the availabilities of social media in future urban development. Three main objects (Collective memory, Heritage interpretation, and Enhance communication) and three aspects of the possible impact on sustainable cultural heritage management (Shared heritage and collective memory, People-centered approach, Cultural expression) were expected initially with a possibility to be extended.

\section{Findings}

\subsection{Outcome 1}

Based on the research design, a total of 19 articles consistently corresponded to the requirements as shown in Table 3. The publication time ranged from 2006 until the present, and the quantity of published articles shows an upward trend along with the time (2006 $n=1,2010 n=1,2015 n=2,2016 n=2,2017 n=5,2018 n=4,2019 n=3)$. Publications since 2015 take a noticeably high proportion $(90 \%)$ as compared to the ones published before $(10 \%)$, which demonstrates the rising attention from scholars and practitioners on testing social media in cultural heritage set in the recent five years.

Moreover, 39 cases from 12 countries all over the world with Australia $(n=1)$, China $(n=1)$, Denmark $(n=1)$, Finland $(n=1)$, Greece $(n=1)$, Italy $(n=3)$, Jordan $(n=1)$, Lebanon $(n=1)$, Nepal $(n=1)$, the Netherlands $(n=20)$, New Zealand $(n=1)$, the UK $(n=4)$, the US $(n=1)$, and Vienna $(n=1)$ are extracted from the articles as shown in Table 4 . The review shows that the highest number of social media engaged heritage sites are located in Europe (30 in total, including Denmark, Finland, Greece, Italy, the Netherlands, and the UK), which represents $75 \%$ of the total. However, according to the UNESCO World Heritage List (2019), properties located in Europe represent just under half $(47 \%)$ of the list, which indicates that using social media on cultural heritage conservation in other regions is still underexplored. Moreover, China, as one of the countries which own the most inscribed heritages, presents unsatisfactory results with only one case. It should be taken into consideration that there could be some statistical bias as the method for retrieval is by no means fully comprehensive, and more suitable cases could be included to expand our current list. 
Table 3. Case collection.

\begin{tabular}{|c|c|c|c|c|c|c|c|}
\hline No. & $\begin{array}{l}\text { Publication } \\
\text { Time }\end{array}$ & $\begin{array}{l}\text { Location } \\
\text { (Nation) }\end{array}$ & Cultural Heritage Object & Applied Social Media & Interactive Method & Object & $\begin{array}{c}\text { Impact on Sustainable } \\
\text { Cultural Heritage } \\
\text { Management }\end{array}$ \\
\hline 1 & 2019 & Greece & Thessaloniki & Website, APP & $\begin{array}{l}\text { Storytelling; } \\
\text { Mapping; } \\
\text { Exhibition; } \\
\text { Crowdsourcing }\end{array}$ & Collective memory & $\begin{array}{l}\text { Shared heritage and } \\
\text { collective memory }\end{array}$ \\
\hline 2 & 2019 & Nether-lands & $\begin{array}{l}19 \text { Dutch heritage projects and } \\
\text { organizations (eg. Amsterdam } \\
\text { Museum, Museum Rotterdam, } \\
\text { etc) }\end{array}$ & $\begin{array}{l}\text { Twitter Facebook Flickr } \\
\text { YouTube Pinterest blogs } \\
\text { Instagram Linkedin } \\
\text { TripAdvisor Website } \\
\text { Interactive map }\end{array}$ & Storytelling; Mapping & Collective memory & $\begin{array}{l}\text { Shared heritage and } \\
\text { collective memory }\end{array}$ \\
\hline 3 & 2019 & Lebanon & $\begin{array}{l}\text { Tripoli and El-Mina municipal } \\
\text { boundaries }\end{array}$ & Flickr & Mapping & Heritage interpretation & People-centered approach \\
\hline 4 & 2018 & Finland & Nikkilä & $\begin{array}{c}\text { Instagram, Twitter, } \\
\text { Facebook, Interactive map }\end{array}$ & $\begin{array}{l}\text { Communication; } \\
\text { Crowdsourcing }\end{array}$ & Enhance communication & People-centered approach \\
\hline 5 & 2018 & Italy & Puglia & Facebook, Twitter & $\begin{array}{l}\text { Communication; } \\
\text { Crowdsourcing }\end{array}$ & Enhance communication & People-centered approach \\
\hline \multirow[b]{2}{*}{6} & \multirow[b]{2}{*}{2018} & Nepal & Kathmandu Valley & \multirow[b]{2}{*}{ Website } & \multirow[b]{2}{*}{ Mapping } & \multirow[b]{2}{*}{ Heritage interpretation } & \multirow[b]{2}{*}{ Cultural expression } \\
\hline & & UK & $\begin{array}{l}\text { Newcastle University } \\
\text { Quadrangle Gateway }\end{array}$ & & & & \\
\hline 7 & 2018 & New Zealand & A Museum & Website & $\begin{array}{l}\text { Photo sharing; } \\
\text { Crowdsourcing }\end{array}$ & $\begin{array}{l}\text { Maintain community } \\
\text { archives }\end{array}$ & $\begin{array}{c}\text { Shared heritage and } \\
\text { collective memory }\end{array}$ \\
\hline 8 & 2018 & $\begin{array}{c}\text { United } \\
\text { Kingdom }\end{array}$ & the North East of Scotland & Facebook & $\begin{array}{l}\text { Photo sharing; } \\
\text { Storytelling }\end{array}$ & Collective memory & People-centered approach \\
\hline 9 & 2017 & $\begin{array}{c}\text { United } \\
\text { Kingdom }\end{array}$ & UCL's Grant Museum & Website, Twitter, APP & $\begin{array}{c}\text { Exhibition; } \\
\text { Crowdsourcing }\end{array}$ & Heritage interpretation & Cultural expression \\
\hline
\end{tabular}


Table 3. Cont.

\begin{tabular}{|c|c|c|c|c|c|c|c|}
\hline No. & $\begin{array}{l}\text { Publication } \\
\text { Time }\end{array}$ & $\begin{array}{l}\text { Location } \\
\text { (Nation) }\end{array}$ & Cultural Heritage Object & Applied Social Media & Interactive Method & Object & $\begin{array}{c}\text { Impact on Sustainable } \\
\text { Cultural Heritage } \\
\text { Management }\end{array}$ \\
\hline \multirow{3}{*}{10} & \multirow{3}{*}{2017} & Netherlands & Anne Frank House & \multirow{3}{*}{ Facebook (Messen-ger) } & \multirow{3}{*}{ Communication } & \multirow{3}{*}{ Heritage interpretation } & \multirow{3}{*}{ Cultural expression } \\
\hline & & Italy & The House Museums of Milan & & & & \\
\hline & & Italy & $\begin{array}{l}\text { The National Museum of the } \\
\text { 21st Century Arts }\end{array}$ & & & & \\
\hline 11 & 2017 & $\begin{array}{l}\text { United } \\
\text { Kingdom }\end{array}$ & $\begin{array}{c}\text { Prehistoric Rock Carvings in } \\
\text { Northumberland }\end{array}$ & Facebook; Website & $\begin{array}{l}\text { Exhibition; } \\
\text { Storytelling }\end{array}$ & Enhance communication & People-centered approach \\
\hline 12 & 2017 & United State & $\begin{array}{l}\text { Smithsonian National Museum } \\
\text { of African American History } \\
\text { and Culture }\end{array}$ & Twitter & $\begin{array}{l}\text { Exhibition; } \\
\text { Storytelling }\end{array}$ & $\begin{array}{l}\text { Increase access for } \\
\text { visitors of color }\end{array}$ & People-centered approach \\
\hline 13 & 2017 & Jordan & Amman & Facebook & $\begin{array}{l}\text { Crowdsourcing; } \\
\text { Official announcement }\end{array}$ & Enhance communication & People-centered approach \\
\hline 14 & 2016 & Australia & Brisbane's built heritage & $\begin{array}{l}\text { Facebook, Instagram, } \\
\text { Pinterest, Twitter }\end{array}$ & $\begin{array}{l}\text { Storytelling; } \\
\text { Crowdsourcing }\end{array}$ & Heritage interpretation & Cultural expression \\
\hline 16 & 2015 & China & Dafo Temple & Weibo & $\begin{array}{l}\text { Photo sharing; } \\
\text { Communication; } \\
\text { Crowdsourcing }\end{array}$ & Equity of the discourse & People-centered approach \\
\hline 17 & 2015 & Denmark & $\begin{array}{l}\text { Contemporary Danish Urban } \\
\text { Cemetery }\end{array}$ & Interactive map & Mapping & Heritage interpretation & Cultural expression \\
\hline 18 & 2010 & Australia & Sydney Opera House & Flickr & Photo sharing & $\begin{array}{l}\text { Collective identity } \\
\text { representation }\end{array}$ & Cultural expression \\
\hline 19 & 2006 & UK & South-east of England & Website & $\begin{array}{l}\text { Communication; } \\
\text { Crowdsourcing; } \\
\text { Official announcement }\end{array}$ & Heritage interpretation & Cultural expression \\
\hline
\end{tabular}


Table 4. The types of applied social media to cultural heritage objects.

\begin{tabular}{|c|c|c|c|c|c|c|c|c|c|c|c|c|c|c|c|}
\hline \multirow{2}{*}{ No. } & \multirow{2}{*}{ Location } & \multirow{2}{*}{ Cultural Heritage Object } & \multicolumn{13}{|c|}{ Applied Social Media } \\
\hline & & & App & Blg & FB & FK & Ins & Lin & Map & Pin & TA & Twi & WB & Web & YT \\
\hline 1 & Greece & Thessaloniki & & & & & & & & & & & & $\bullet$ & \\
\hline 3 & Finland & Nikkilä & & & $\bullet$ & & $\bullet$ & & $\bullet$ & & & $\bullet$ & & & \\
\hline 4 & Italy & Puglia & & & $\bullet$ & & & & & & & $\bullet$ & & & \\
\hline 5 & NewZealand & amuseum & & & & & & & & & & & & $\bullet$ & \\
\hline 6 & UK & theNorthEastofScotland & & & $\bullet$ & & & & & & & & & & \\
\hline 7 & UK & UCL'sGrantMuseum & $\bullet$ & & & & & & & & & $\bullet$ & & $\bullet$ & \\
\hline 8 & UK & PrehistoricRockCarvingsinNorthumberland & & & $\bullet$ & & & & & & & & & & \\
\hline 9 & US & NationalMuseumofAfricanAmericanHistoryandCulture & & & & & & & & & & $\bullet$ & & & \\
\hline 10 & Jordan & Amman & & & • & & & & & & & & & & \\
\hline 11 & Australia & Brisbane'sbuiltheritage & & $\bullet$ & $\bullet$ & & $\bullet$ & & & & & $\bullet$ & & & \\
\hline 12 & Vienna & theViennaWerkbundestate & & & $\bullet$ & $\bullet$ & & & & $\bullet$ & & & & $\bullet$ & \\
\hline 14 & Danmark & ContemporaryDanishUrbanCemetery & & & & & & & $\bullet$ & & & & & & \\
\hline 15 & Australia & SydneyOperaHouse & & & & $\bullet$ & & & & & & & & & \\
\hline 16 & Netherlands & AmsterdamMuseum & & $\bullet$ & $\bullet$ & $\bullet$ & & & & $\bullet$ & & $\bullet$ & & $\bullet$ & $\bullet$ \\
\hline 17 & Netherlands & MuseumhetSchip & $\bullet$ & & $\bullet$ & & & & & & $\bullet$ & $\bullet$ & & & $\bullet$ \\
\hline 18 & Netherlands & BelvédèreRotterdam & & & $\bullet$ & & $\bullet$ & $\bullet$ & & & & $\bullet$ & & & \\
\hline 19 & Netherlands & BijlmerMuseum & & $\bullet$ & $\bullet$ & & & & & & & & & & \\
\hline 20 & Netherlands & FinancieelErfgoedopdeKaart & & & $\bullet$ & & & & $\bullet$ & & & & & & $\bullet$ \\
\hline 21 & Netherlands & GeheugenvanOost & & & $\bullet$ & & & & & $\bullet$ & & $\bullet$ & & $\bullet$ & \\
\hline 22 & Netherlands & TheHistoricalMuseumofThe & & & $\bullet$ & $\bullet$ & • & & & & & $\bullet$ & & & • \\
\hline
\end{tabular}


Table 4. Cont.

\begin{tabular}{|c|c|c|c|c|c|c|c|c|c|c|c|c|c|c|c|}
\hline \multirow{2}{*}{ No. } & \multirow{2}{*}{ Location } & \multirow{2}{*}{ Cultural Heritage Object } & \multicolumn{13}{|c|}{ Applied Social Media } \\
\hline & & & App & Blg & FB & FK & Ins & Lin & Map & Pin & TA & Twi & WB & Web & YT \\
\hline 23 & Netherlands & HagueImagineIC & & & $\bullet$ & $\bullet$ & & & & & & $\bullet$ & & & $\bullet$ \\
\hline 25 & Netherlands & MurenTransvaal & & & $\bullet$ & & & & & & & & & & \\
\hline 26 & Netherlands & OngekendBijzonder & & & $\bullet$ & & & & & & & $\bullet$ & & & $\bullet$ \\
\hline 27 & Netherlands & OudAmsterdam & & & $\bullet$ & & & & & & & $\bullet$ & & & \\
\hline 28 & Netherlands & RotterdaminKaart & & & & & & & $\bullet$ & & & & & & \\
\hline 29 & Netherlands & RotterdamVertelt & & & • & & & & & & & & & & \\
\hline 30 & Netherlands & StadsarchiefRotterdam & & & - & $\bullet$ & & & & & & $\bullet$ & & & • \\
\hline 31 & Netherlands & WederopbouwRotterdam & & & $\bullet$ & & & & & & & $\bullet$ & & & \\
\hline 32 & Netherlands & ZichtopMaastricht & & & $\bullet$ & & & & & & & $\bullet$ & & $\bullet$ & $\bullet$ \\
\hline 33 & Netherlands & HaagseHerinneringen & & & $\bullet$ & & & & & & & & & $\bullet$ & • \\
\hline 34 & Netherlands & Mappingslavery & & & $\bullet$ & & & & $\bullet$ & & & • & & & \\
\hline 36 & UK & NewcastleUniversityQuadrangleGateway & & & & & & & & & & & $\bullet$ & & \\
\hline 37 & Netherlands & AnneFrankHouse & & & $\bullet$ & & & & & & & & & & \\
\hline 38 & Italy & TheHouseMuseumsofMilan & & & $\bullet$ & & & & & & & & & & \\
\hline 39 & Italy & TheNationalMuseumofThe21stCenturyArts & & & $\bullet$ & & & & & & & & & & \\
\hline
\end{tabular}

Note. Blg = blogs, FB = Facebook, FK = Flickr, Ins = Instagram, Lin = LinkedIn, Pin = Pinterest, TA = Trip Advisor, Twi = Twitter, WB = Weibo, YT = YouTube. 
In addition, the study further categorized all the extracted 39 cultural heritage objects into four topics according to their attribution and features as shown in Table 5. We ranked the social media, according to the usage frequency of each social media platform. Building $(n=5)$, City $(n=6)$, Landscape $(n=4)$, Museum $(n=24)$. Seeing Figure 1 , it is easy to find out that museums are the pioneers of involving social media tools (62\%) and play an important role in managing digital heritage. In the opposite case, the focus on involving social media in conserving buildings, cities, and landscapes is relatively less.

We suggest that museums are seen as core facilitators of cultural heritage for the general public. As museums usually play a role in daily life as the carriers of the exhibitions, cultural events, archives, collections of cultural relics, etc. Such activities are often associated with budgets for public engagement, which allows social media tools to be developed and promoted.

Table 5. Analysis and Categorization of the Extracted Cultural Heritage Objects.

\begin{tabular}{|c|c|c|}
\hline Categories & No. & Cultural Heritage Object \\
\hline \multirow{24}{*}{ Museum } & 1 & A museum \\
\hline & 2 & Amsterdam Museum \\
\hline & 3 & Belvédère Rotterdam \\
\hline & 4 & Bijlmer Museum \\
\hline & 5 & Financieel Erfgoed op de Kaart \\
\hline & 6 & Geheugen van Oost \\
\hline & 7 & Haagse Herinneringen \\
\hline & 8 & Hague Imagine IC \\
\hline & 9 & Mapping slavery \\
\hline & 10 & Muren Transvaal \\
\hline & 11 & Museum het Schip \\
\hline & 12 & Museum Rotterdam Museum Zonder \\
\hline & 13 & Ongekend Bijzonder \\
\hline & 14 & Oud Amsterdam \\
\hline & 15 & Rotterdam in Kaart \\
\hline & 16 & Rotterdam Vertelt \\
\hline & 17 & Smithsonian National Museum of African American History and Culture \\
\hline & 18 & Stadsarchief Rotterdam \\
\hline & 19 & The Historical Museum of The \\
\hline & 20 & The House Museums of Milan \\
\hline & 21 & The National Museum of The 21st Century Arts \\
\hline & 22 & UCL's Grant Museum \\
\hline & 23 & Wederopbouw Rotterdam \\
\hline & 24 & Zicht op Maastricht \\
\hline \multirow{6}{*}{ City } & 1 & Thessaloniki \\
\hline & 2 & Amman \\
\hline & 3 & Nikkilä \\
\hline & 4 & Puglia \\
\hline & 5 & the North East of Scotland \\
\hline & 6 & Tripoli and El-Mina municipal boundaries \\
\hline \multirow{5}{*}{ Building } & 1 & Anne Frank House \\
\hline & 2 & Brisbane's built heritage \\
\hline & 3 & Dafo Temple \\
\hline & 4 & Sydney Opera House \\
\hline & 5 & the Vienna Werkbund estate \\
\hline \multirow{4}{*}{ Landscape } & 1 & Contemporary Danish Urban Cemetery \\
\hline & 2 & Kathmandu Valley \\
\hline & 3 & Newcastle University Quadrangle Gateway \\
\hline & 4 & Prehistoric Rock Carvings in Northumberland \\
\hline
\end{tabular}




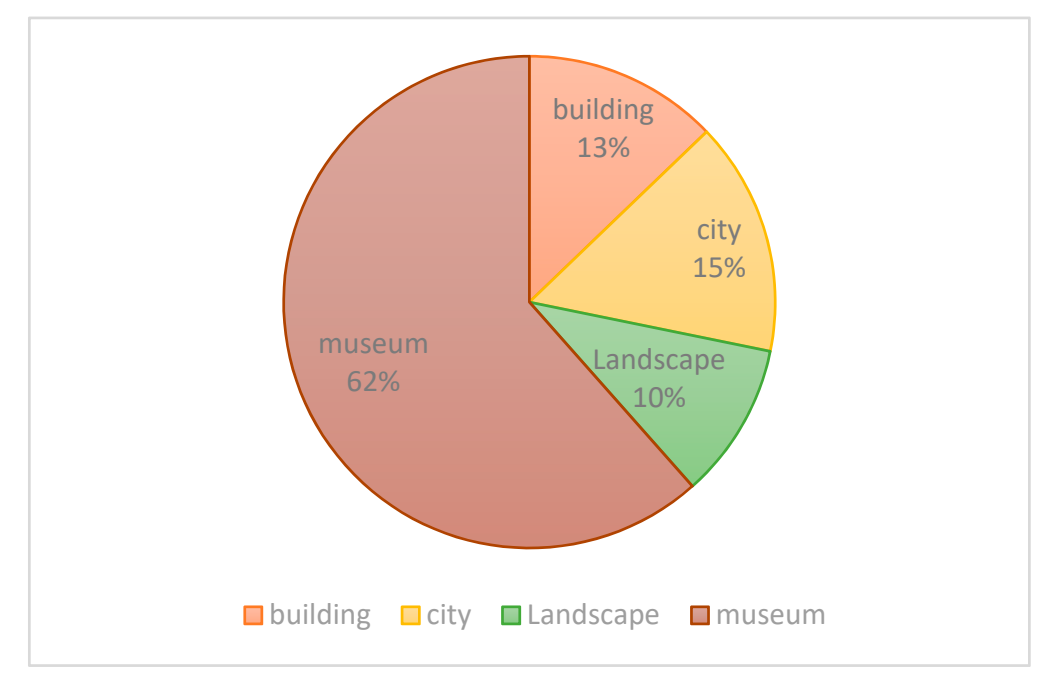

Figure 1. The proportion of the 4 identified aspects of the selected cases.

Whereas on a wider scale, citizens are not always aware that the historic buildings, cities, or landscapes that they use or live in should be part of the need-to-be-conserved heritage. This is often due to a lack of engagement at a city or landscape scale. Therefore, it is important that local governments, planners, and developers raise awareness on this issue with the general public so that there is a good understanding of the broader definition of cultural heritage and its importance. This requires the need for citizen participation in the planning and development process of both urban and rural landscapes. This requires investment and capacity-building-type activities that equip citizens with knowledge and skills to offer helpful feedback, suggestions, and practices. Social media tools provide an ideal platform for this approach.

\subsection{Outcome 2}

Regarding participatory social media tools, Figure 2 demonstrates that Facebook ranks in first place $(30 \%)$, followed by Twitter $(19 \%)$, and customized websites $(12 \%)$, indicating that text-based platforms are the most popular ones among the global audience. Furthermore, photo and video sharing apps, YouTube (10\%), Flickr (7\%), Instagram (5\%), Pinterest (3\%), and GIS-based interactive maps (5\%) have also been applied. Besides, other digital platforms listed as Blog, Pinterest, interactive apps, LinkedIn, TripAdvisor, Weibo took only a small part of this field. Some researchers and developers admitted that popularity is the main decisive factor to target their choices [50]. Thus, it is not a surprise that Facebook becomes their favorite testing field because it is currently the most popular platform with 2.3 billion users.

The result of the interactive method analysis as shown in Figure 3 presents a relatively equal frequency of involving each way. Data analysis by crowdsourcing or other computing means ended up with the highest score $(n=9)$, while Communication $(n=5)$; Photosharing $(n=5)$; Mapping $(n=5)$; Storytelling $(n=5)$; Exhibition $(n=3)$; Official announcement $(n=2)$ are noticeably lower. It reveals that there is almost no bias concerning the operation process, which means researchers and experts examine and explore various aspects and directions led by social media.

The objects are briefly categorized into five groups: Heritage interpretation $(n=8)$, Enhance communication $(n=5)$, Collective memory $(n=4)$, Equity of the discourse $(n=2)$, and Maintain community archives $(n=1)$. Meanwhile, within the column Impact on Sustainable Cultural Heritage Management, People-centered approach $(n=9)$ and Cultural expression $(n=9)$ are the most popular rungs achieved within global heritage management. While the aspect of Shared heritage and collective memory $(n=3)$ received less attention. Although Cultural expression and heritage interpretation are absolutely the main streams, 
the efforts of scholars to Enhance community communication in the People-centered approach is not ignorable.

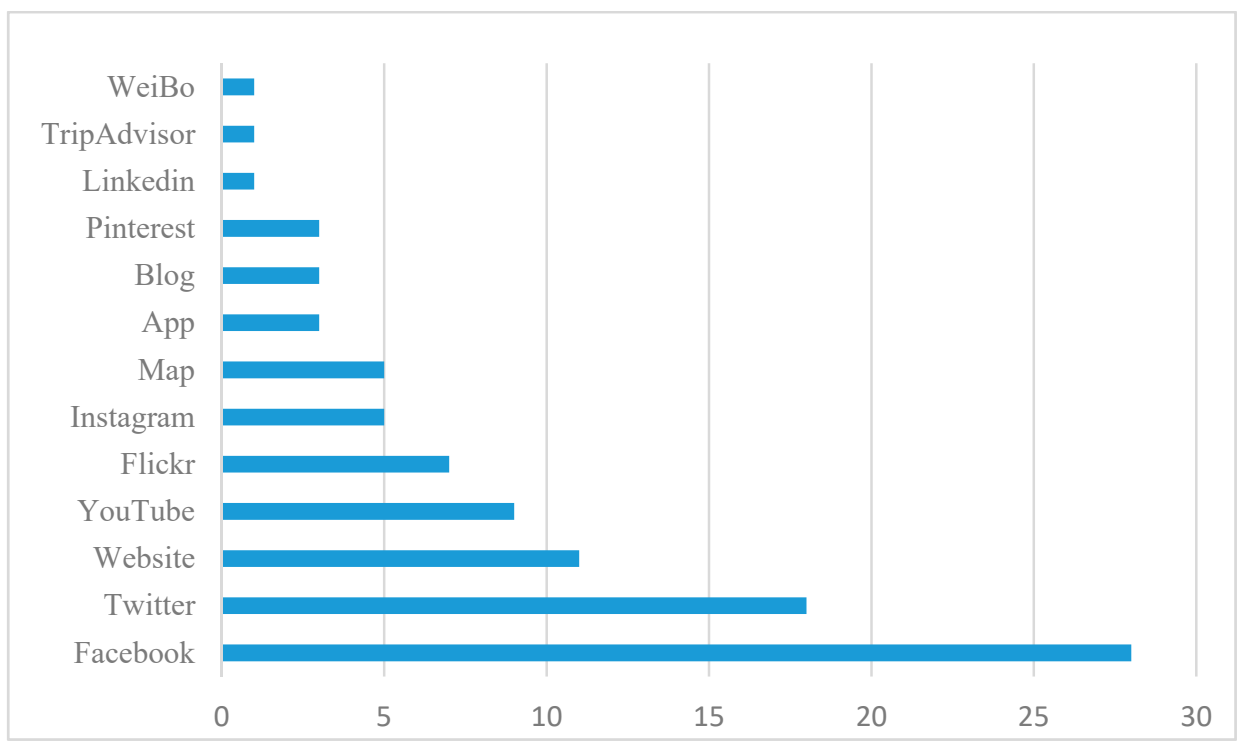

Figure 2. The usage frequency of each social media tool.

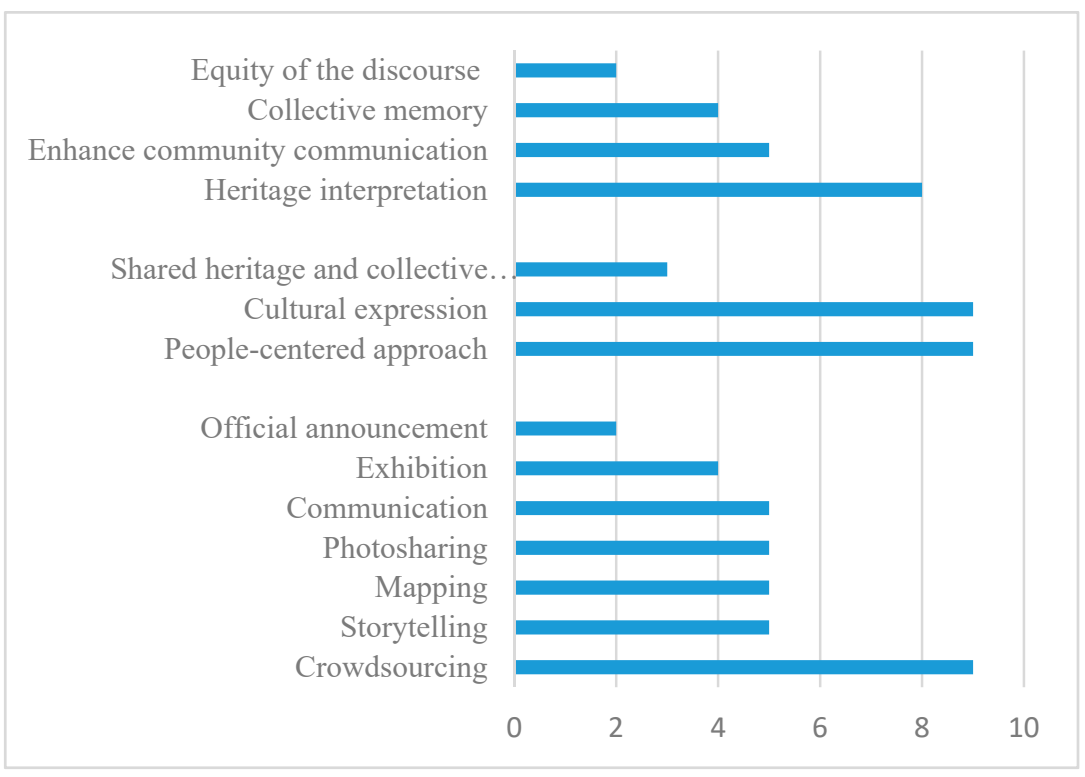

Figure 3. The quantitative result of the interactive method.

\section{Conclusions}

Using digital tools to engage the local community in protecting and promoting the values of cultural heritage is gaining more and more attention [13,48]. Digital technologies can improve conservation and preservation techniques, enrich archives with interactive media, map heritage with the Geographic Information System, augment participatory experiences, promote communication among stakeholders, and deepen the understanding of the cultural attachment $[63,64]$. Social media is considered to be one of the most important facilitators to promote the double side collaboration of authorities and citizens [65].

The study aimed to offer a comprehensive global review of the availability and functionalities of social media and to identify tools and platforms that are applied currently to the current cultural heritage management process. The approach of the systematic review was structured with a PIST tool. A total of 19 articles were eventually selected, from 
which 39 cases were extracted, identified, and analyzed. The review indicates that almost three-quarters of the identified practices are mainly concentrated in Europe. However, taking into account the development of digital technology and the economy, further efforts toward digital-enabled heritage conservation could be undertaken by other governments, agencies, NGOs, and communities around the world.

Overall, social media tools are generally applied to museums instead of urban heritage buildings (monuments), and landscapes. The 39 cases have been analyzed with regard to the applied social media tools, interactive methods for the heritage objects, and the impact on sustainable cultural heritage management. Facebook is considered as the most popular social media out of 13 , while the assessment of interactive ways of social media and heritage management shows a relatively average score. Meanwhile, heritage interpretation is regarded as the most involved purpose as compared to enhancing communication, collective memory, equity of the discourse, and maintaining community archives. The application of social media tools also shows a greater impact on the two aspects of the sustainability of heritage conservation: the people-centered approach and cultural expression.

The people-centered approaches, such as the equity of discourses across cultural diversity, nation, religion, gender, etc., should be supported and highlighted widely on social media platforms. Despite UNESCO emphasizing community communication and collaboration in heritage management as a key priority, the global application of social media currently still tends to broadcast the heritage value instead of strengthening the collaboration among stakeholders. However, some countries with centralized governance and regulatory systems, such as China, recommend a localized and contextualized bottomup approach for social media in order to encourage local residents to better engage in both decision-making and benefit-sharing process.

Based on the extensive literature inventory, the study has not only contributed to a comprehensive picture of the current research in this area but also detailed a series of practical cases and defined the involved approaches, objects, and main significance. However, further studies and cases are required to explore how the sector can make the most out of the current social media platforms in diverse cultural backgrounds, within the context of rapid urbanization context.

Author Contributions: X.L.: Conceptualization, Methodology, Formal analysis, Investigation, Data curation, Writing original draft; Y.L.: Formal analysis, Investigation, Data curation, Writing—original draft; J.M.: Methodology, Writing-review and editing, Supervision. All authors have read and agreed to the published version of the manuscript.

Funding: This research received no external funding.

Conflicts of Interest: The authors declare that they have no known competing financial interests or personal relationships that could have appeared to influence the work reported in this paper.

\section{References}

1. Li, J.; Krishnamurthy, S.; Pereira Roders, A.; van Wesemael, P. Community participation in cultural heritage management: A systematic literature review comparing Chinese and international practices. Cities 2020, 96, 102476. [CrossRef]

2. Jokilehto, J. Definition of Cultural Heritage: References to Documents in History; ICCROM Working Group Heritage and Society: Rome, Italy, 2005.

3. Roders, P.; Bandarin, F. Reshaping Urban Conservation: The Historic Urban Landscape Approach in Action; Springer: Berlin, Germany, 2019.

4. Court, S.; Wijesuriya, G. People-centred approaches to the conservation of cultural heritage: Living heritage. In Heritage, Conservation and Communities: Engagement, Participation and Capacity Building; Chitty, G., Ed.; Routledge: New York, NY, USA, 2017; pp. 34-50.

5. Poulios, I. Discussing strategy in heritage conservation: Living heritage approach as an example of strategic innovation. J. Cult. Herit. Manag. Sustain. Dev. 2014, 4, 16-34. [CrossRef]

6. Bideau, F.G.; Yan, H. Historic urban landscape in Beijing: The gulou project and its contested memories. In Chinese Heritage in the Making; Maags, C., Svensson, M., Eds.; Amsterdam University Press: Amsterdam, The Netherlands, 2018 ; pp. 93-118.

7. Taylor, K. The Historic Urban Landscape paradigm and cities as cultural landscapes. Challenging orthodoxy in urban conservation. Landsc. Res. 2016, 41, 471-480. [CrossRef] 
8. Bandarin, F.; van Oers, R. Reconnecting the City: The Historic Urban Landscape Approach and the Future of Urban Heritage; John Wiley \& Sons: New York, NY, USA, 2014.

9. Borona, G.; Ndiema, E. Merging research, conservation and community engagement. J. Cult. Herit. Manag. Sustain. Dev. 2014, 4, 184-195. [CrossRef]

10. Chitty, G. Heritage, Conservation and Communities: Engagement, Participation and Capacity Building; Taylor \& Francis: Abingdon, UK, 2016.

11. Bandarin, F.; van Oers, R. The Historic Urban Landscape: Managing Heritage in an Urban Century; John Wiley \& Sons: New York, NY, USA, 2012.

12. Settis, S. We the Citizens, English Translation of chapter 7 of Paesaggio, Costituzione, Cemento: La Battaglia per L'ambiente Contro il Degrado Civile (Einaudi, 2010). Calif. Ital. Stud. 2011, 2. Available online: https://escholarship.org/content/qt7c90g6 dp/qt7c90g6dp.pdf (accessed on 23 September 2019).

13. Affleck, J.; Kvan, T. A Virtual community as the context for discursive interpretation: A role in cultural heritage engagement. Int. J. Herit. Stud. 2008, 14, 268-280. [CrossRef]

14. Li, J.; Krishnamurthy, S.; Pereira Roders, A.; van Wesemael, P. State-of-the-practice: Assessing community participation within Chinese cultural World heritage properties. Habitat Int. 2020, 96, 102-107. [CrossRef]

15. Ferreira, T.C. Bridging planned conservation and community empowerment: Portuguese case studies. J. Cult. Herit. Manag. Sustain. Dev. 2018. Available online: https://repositorio-aberto.up.pt/bitstream/10216/119597/2/330445.pdf (accessed on 25 December 2020).

16. MacRae, G. Universal heritage meets local livelihoods: "awkward engagements" at the world cultural heritage listing in Bali. Int. J. Herit. Stud. 2017, 23, 846-859. [CrossRef]

17. Verdini, G.; Frassoldati, F.; Nolf, C. Reframing China's heritage conservation discourse. Learning by testing civic engagement tools in a historic rural village. Int. J. Herit. Stud. 2017, 23, 317-334. [CrossRef]

18. Ginzarly, A.; Roders, P.; Teller, J. Mapping historic urban landscape values through social media. J. Cult. Herit. 2019, 36, 1-11. [CrossRef]

19. Diaz-Andreu, M. Introduction to the themed section "digital heritage and the public". Int. J. Herit. Stud. 2017, 23. Available online: https: / / www.tandfonline.com/doi/pdf/10.1080/13527258.2017.1286780?needAccess=true (accessed on 25 December 2020). [CrossRef]

20. Kitchin, R.; Dodge, M. Code/Space: Software and Everyday Life; MIT Press: Cambridge, MA, USA, 2011.

21. Corallo, A.; Trono, A.; Fortunato, L.; Pettinato, F.; Schina, L. Cultural event management and urban e-planning through bottom-up user participation. Int. J. E Plan. Res. 2018, 7, 15-33. [CrossRef]

22. Muhammad, T.; Kim, K. Sustainable and ICT-enabled development in developing areas: An e-heritage e-commerce service for handicraft marketing. In Proceedings of the International Conference on Sustainable Development and Green Technology (SDGT 2017), Chiayi, Taiwan, 24-26 November 2017; Volume 989. Available online: https:/ /iopscience.iop.org/article/10.1088/1742-659 6/989/1/012009/pdf (accessed on 10 January 2021).

23. Garduño Freeman, C. Photosharing on Flickr: Intangible heritage and emergent publics. Int. J. Herit. Stud. 2010, 16, 4-5. [CrossRef]

24. Giaccardi, E. Heritage and Social Media: Understanding Heritage in a Participatory Culture; Routledge: New York, NY, USA, 2012.

25. Psomadaki, I.; Dimoulas, C.A.; Kalliris, G.M.; Paschalidis, G. Digital storytelling and audience engagement in cultural heritage management: A collaborative model based on the Digital City of Thessaloniki. J. Cult. Herit. 2019, 36, 12-22. [CrossRef]

26. Dhonju, H.K.; Xiao, W.; Mills, J.P.; Sarhosis, V. Share our cultural heritage (SOCH): Worldwide 3D heritage reconstruction and visualization via web and mobile GIS. ISPRS. Int. J. Geo. Inf. 2018, 7, 360. [CrossRef]

27. Lafreniere, D.; Weidner, L.; Trepal, D.; Scarlett, S.F.; Arnold, J.; Pastel, R. Public participatory historical GIS. Hist. Methods J. Quant. Interdiscip. Hist. 2019, 52, 132-149. [CrossRef]

28. Nummi, P. Crowdsourcing local knowledge with PPGIS and social media for urban planning to reveal intangible cultural heritage. Urban. Plan. 2018, 3, 100-105. [CrossRef]

29. Shaw, B.J.; Draux, H.; Martín, M.G.; Martin, J.; Bieling, C. Contributions of citizen science to landscape democracy: Potentials and challenges of current approaches. Landsc. Res. 2017, 42, 831-844. [CrossRef]

30. Claisse, C.; Ciolfi, L.; Petrelli, D. Containers of stories: Using co-design and digital augmentation to empower the museum community and create novel experiences of heritage at a house museum. Des. J. 2017, 20, S2906-S2918. [CrossRef]

31. Sanders, E.B.-N.; Stappers, P.J. Co-creation and the new landscapes of design. CoDesign 2008, 4, 5-18. [CrossRef]

32. Champion, E.; Rahaman, H. 3D digital heritage models as sustainable scholarly resources. Sustainability 2019, 11, 2425. [CrossRef]

33. Deng, Z.; Lin, Y.; Zhao, M.; Wang, S. Collaborative planning in the new media age: The Dafo temple controversy, China. Cities 2015, 45, 41-50. [CrossRef]

34. Hood, C.; Reid, P. Social media as a vehicle for user engagement with local history: A case study in the North East of Scotland. J. Doc. 2018, 74. Available online: https://www.emerald.com/insight/content/doi/10.1108/JD-12-2017-0167/full/pdf?title= social-media-as-a-vehicle-for-user-engagement-with-local-history-a-case-study-in-the-north-east-of-scotland (accessed on 26 December 2020). [CrossRef] 
35. de Filippi, F.; Coscia, C.; Guido, R. MiraMap: A collective awareness platform to support open policy-making and the integration of the citizens' perspective in urban planning and governance. In Technologies for Development; Springer: Cham, Germany, 2018; pp. 127-139. [CrossRef]

36. Kleinhans, R.; Ham, M.V.; Evans-Cowley, J. Using social media and mobile technologies to foster engagement and self-organization in participatory urban planning and neighbourhood governance. Plan. Pract. Res. 2015, 30, 237-247. [CrossRef]

37. Sroczynska, J. Role of ICT Technologies in the Conservation of Building Monuments; DWE: Wroclaw, Poland, $2012 ;$ pp. $1309-1316$.

38. Cotterill, S.; Hudson, M.; Lloyd, K.; Outterside, J.; Peterson, J.; Coburn, J.; Thomas, U.; Tiplady, L.; Robinson, P.; Heslop, P. Co-curate: Working with schools and communities to add value to open collections. J. Interact. Media Educ. 2016, 14, 1-9. [CrossRef]

39. Yeates, R.; Guy, D. Collaborative working for large digitisation projects. Program. Electron. Libr. Inf. Syst. 2006, 40, 137-156. [CrossRef]

40. Aigner, A. Heritage-making "from below": The politics of exhibiting architectural heritage on the Internet-A case study. Int. J. Herit. Stud. 2016, 22, 181-199. [CrossRef]

41. Beel, D.E.; Wallace, C.D.; Webster, G.; Nguyen, H.; Tait, E.; MacLeod, M.; Mellish, C. Cultural resilience: The production of rural community heritage, digital archives and the role of volunteers. J. Rural Stud. 2017, 54, 459-468. [CrossRef]

42. Prictor, S.; Huebner, H.J.; Teare, A.; Burchill, L.; Kaye, J. Australian aboriginal and torres strait Islander collections of genetic heritage: The legal, ethical and practical considerations of a dynamic consent approach to decision making. J. Law. Med. Ethics 2020, 48, 137-156. [CrossRef]

43. Prastyawan, A.; Isbandono, P. The Efforts of Joyoboyo Citizens in Preserving Traditional Children's Games through Dolanan Village. In Proceedings of the 1st International Conference on Social Sciences (ICSS 2018), Bali, Indonesia, 18-19 October 2018; pp. 378-381. [CrossRef]

44. Rubino, I.; Barberis, C.; Xhembulla, J.; Malnati, G. Integrating a location-based mobile game in the museum visit: Evaluating visitors' behaviour and learning. JOCCH 2015, 8, 15. [CrossRef]

45. Yamamura, T. Revitalization of historical heritage using pop culture in Japan: Shiroishi city and the game/anime Sengoku Basara. Tour. Anal. 2015, 20,1-18. [CrossRef]

46. Arrigoni, G.; Schofield, T.; Pisanty, D.T. Framing collaborative processes of digital transformation in cultural organisations: From literary archives to augmented reality. Mus. Manag. Curatorship 2019, 35, 424-445. [CrossRef]

47. Spacca, S.; Dellapiana, E.; Sanna, A. Promoting industrial cultural heritage by augmented reality: Application and assessment. Open Cybern. Syst. J. 2018, 12, 61-71. [CrossRef]

48. Jeffrey, S.; Jones, S.; Maxwell, M.; Hale, A.; Jones, C. 3D visualisation, communities and the production of significance. Int. J. Herit. Stud. 2020, 3, 885-900. [CrossRef]

49. Statham, N. Scientific rigour of online platforms for 3d visualisation of heritage. Virtual Archaeol. Rev. 2019, 10. [CrossRef]

50. Fernandez, G.; Tammi, K.; Joutsiniemi, A. Extending the life of virtual heritage: Reuse of Tls point clouds in synthetic stereoscopic spherical images. Int. Arch. Photogramm. Remote Sens. Spat. Inf. Sci. 2017, 42, 317-323. [CrossRef]

51. Hurley, A. Chasing the frontiers of digital technology public history meets the digital divide. Publ. Hist. 2016, 38, 69-88. [CrossRef]

52. Loren-Mendez, M.; Pinzon-Ayala, D.; Ruiz, R.; Alonso-Jimenez, R. Mapping heritage: Geospatial online databases of historic roads. The case of the N-340 roadway corridor on the Spanish Mediterranean. ISPRS Int. J. Geo Inf. 2018, 7, 134. [CrossRef]

53. Yang, W.B.; Yen, Y.N. A planning by using digital technology in the reconstruction of cultural heritage sites-A case study of qiong-lin settlement in Kinmen area. In ICOMOS/ISPRS International Scientific Committee on Heritage Documentation (CIPA), Proceedings of the 26th International CIPA Symposium -Digital Workflows for Heritage Conservation, Ottawa, ON, Canada, 28 August-1 September 2017; Hayes, J., Ouimet, C., Quintero, M.S., Fai, S., Smith, L., Eds.; ISPRS: Hannover, Germany, 2017; Volume 42-2, pp. 719-724. [CrossRef]

54. van der Hoeven, A. Historic urban landscapes on social media: The contributions of online narrative practices to urban heritage conservation. City Cult. Soc. 2019, 17, 61-68. [CrossRef]

55. Wilson, K.; Desha, C. Engaging in design activism and communicating cultural significance through contemporary heritage storytelling A case study in Brisbane, Australia. J. Cult. Herit. Manag. Sustain. Dev. 2016, 6, 271-286. [CrossRef]

56. Spruce, L.; Leaf, K. Social media for social justice. J. Mus. Educ. 2017, 42, 41-53. [CrossRef]

57. Magro, J. A review of social media use in e.-government. Adm. Sci. 2012, 2, 148-161. [CrossRef]

58. Tzouganatou, A. Can heritage bots thrive? Toward future engagement in cultural heritage. Adv. Archaeol. Pract. 2018, 6, 377-383. [CrossRef]

59. Svensson, M.; Maags, C. Mapping the Chinese heritage regime: Ruptures, governmentality, and agency. In Chinese Heritage in the Making: Experiences, Negotiations and Contestations; Svensson, M., Maags, C., Eds.; Amsterdam University Press: Amsterdam, The Netherlands, 2018; pp. 11-38. [CrossRef]

60. Sabra, J.B.; Andersen, H.J.; Rodil, K. Hybrid cemetery culture: Making death matter in cultural heritage using smart mobile technologies. In Proceedings of the 2015 International Conference on Culture and Computing (Culture Computing), Kyoto, Japan, 17-19 October 2015; pp. 167-174. [CrossRef]

61. Eriksen, M.B.; Frandsen, T.F. The impact of patient, intervention, comparison, outcome (PICO) as a search strategy tool on literature search quality: A systematic review. J. Med. Libr. Assoc. JMLA 2018, 106, 420-431. [CrossRef] [PubMed] 
62. Methley, M.; Campbell, S.; Chew-Graham, C.; McNally, R.; Cheraghi-Sohi, S. PICO, PICOS and SPIDER: A comparison study of specificity and sensitivity in three search tools for qualitative systematic reviews. BMC Health Serv. Res. 2014, 14, 579. [CrossRef]

63. Miles, H.C.; Wilsont, A.T.; Labrosse, F.; Tiddeman, B.P. Alternative representations of 3D-reconstructed heritage data. ACM J. Comput. Cult. Herit. 2016, 9. [CrossRef]

64. Popple, S. The new Reithians: Pararchive and citizen animateurs in the BBC digital archive. Converg. Int. J. Res. New Media Technol. 2015, 21, 132-144. [CrossRef]

65. Falco, E.; Kleinhans, R. Digital participatory platforms for co-production in urban development: A systematic review. In Crowdsourcing: Concepts, Methodologies, Tools, and Applications; IGI Global: Hershey, PA, USA, 2019; pp. 663-690. [CrossRef] 